\title{
Thermal Feature of a Modified Solar Phase Change Material Storage Wall System
}

\author{
Chenglong Luo $\mathbb{D}^{1},{ }^{1}$ Lijie Xu $\mathbb{D}^{D},{ }^{2}$ Jie Ji $\left(\mathbb{D},{ }^{2}\right.$ Mengyin Liao, ${ }^{1}$ and Dan Sun ${ }^{1}$ \\ ${ }^{1}$ Institute of Energy Research, Jiangxi Academy of Sciences, Nanchang 330096, China \\ ${ }^{2}$ Department of Thermal Science and Energy Engineering, University of Science and Technology of China, Hefei 230027, China
}

Correspondence should be addressed to Chenglong Luo; xxlong@ustc.edu and Jie Ji; jijie@ustc.edu.cn

Received 25 August 2017; Accepted 11 January 2018; Published 29 March 2018

Academic Editor: Zhonghao Rao

Copyright ( $) 2018$ Chenglong Luo et al. This is an open access article distributed under the Creative Commons Attribution License, which permits unrestricted use, distribution, and reproduction in any medium, provided the original work is properly cited.

This work is to study a novel solar PCM storage wall technology, that is, a dual-channel and thermal-insulation-in-the-middle type solar PCM storage wall (MSPCMW) system. The system has the following four independent functions, passive solar heating, heat preservation, heat insulation, and passive cooling, and it can agilely cope with the requirements of climatization of buildings in different seasons throughout the year and is exactly suitable for building in regions characterized by hot summer and cold winter. The present work experimentally analyzes thermal feature of the system working in summer and winter modes, respectively.

\section{Introduction}

The application of solar energy in buildings to reduce the final energy consumption of conventional energy is an important approach to develop a low-carbon society. The way the phase change material (PCM) provides indirect heat storage is related to energy absorption, which turns into latent heat instead of self-temperature rise. Phase change material (PCM) has strengths of small volume, low temperature, and high heat storage. Therefore, it is a good and efficient heat storage material to be used in building climatization. Hence, the investigation of applying the combination of PCM storage technology and solar energy technology to energy efficient building emerges and receives more and more attention.

Focusing on reducing energy consumption for space heating in building, much work has been done to study and use Trombe wall system which is a high-efficiency simple structure that does not require maintenance [1]. Although this system has been well developed, hurdles remain such as the low annual utilization rate in places with hot and lengthy summer and the often suffering problem of summer overheating $[2,3]$. Therefore, its broad application, improvement, and development have been implemented in the decades since it was proposed. Jie et al. $[4,5]$ made a lot of efforts on investigation of a PV-Trombe wall system. Koyunbaba et al. [6] proposed a BIPV Trombe wall model by computational fluid dynamics (CFD) analysis. The threedimensional model for the shutter structure of Trombe wall was established in [7], and the comparison with experimental data and an optimal design scheme were conducted. But there are a few research work for the combination of Trombe wall technology and PCM envelope structure.

With regard to the combination of solar energy application technology and PCM envelope structure, current researches and discussions mainly focus on PCM floor [8], PCM wall [9-12], and PCM roof [13, 14]. Soares et al. [15] demonstrated that the approach of combining solar energy utilization technology and PCM envelope structure can effectively reduce the room temperature fluctuation in solar energy building caused by lack of solar energy during the night or uncertain weather, thus enhancing the in-room thermal comfort. However, some large areas of China are characterized by hot summers and cold winters and usually require more than three months of air conditioning cooling. In winter, buildings need heating/heat preservation, while in summer they need heat cooling/insulation. Since solar energy is a thermal energy, it can be used conveniently for building heating in winter, but it can also cause overheating and heavy load of air conditioner in summer. Thus, in regions with hot 
summers and cold winters, current solar PCM storage technology cannot fully satisfy the application requirements.

Based upon the analysis above, a former work proposed a novel solar PCM storage wall technology that combines Trombe-wall-like technology and phase change material storage technology, that is, a dual-channel and thermalinsulation-in-the-middle type solar PCM storage wall (MSPCMW) system [16]. This system has the following four independent functions: passive heating, heat preservation, heat insulation, and passive cooling. Therefore, it can easily cope with the requirements of different seasons throughout the year when applied to buildings in regions with hot summers and cold winters. To deeply experimentally analyze thermal feature of the system working in summer and winter modes, respectively, temperature variation and distribution of PCM plates, insulated absorbing plate, and air channels are studied by comparison of temperature difference between the monitoring nodes in the present work.

\section{Principles of MSPCMW System and Experiment Introduction}

MSPCMW system is a combination of Trombe-wall-like technology and phase change material storage technology. A schematic of the system is shown in Figure 1, mainly consisting of a MSPCMW module and a hot-box room with indoor upper and lower vents. The module includes PCM wall, thermal insulation layer, interior and exterior flow channels, heat-absorbing aluminum plate covered by selective absorption coating, indoor upper and lower vents, outdoor upper and lower vents, insulation layer upper and lower vents, glass cover board, and frame. Heat-absorbing aluminum plate and thermal insulation layer are combined as insulated absorbing plate. The structure in which interior and exterior flow channels are separated by thermal insulation layer differs from the single-channel structure of conventional Trombe wall system. The detailed operation modes and functions are as follows:

Summer mode: (a) Heat insulation mode: in summer's daytime, when building needs thermal insulation protection, the indoor and middle layer upper and lower vents are closed, while the outdoor ones are kept opened. Ambient wind pressure together with thermosiphon pressure would form a circular flow between the exterior channel and the outdoor air that takes the solar energy absorbed by aluminum plate back to the environment. Meanwhile, the thermal insulation layer prevents heat conduction into the room, reducing building's absorption of solar energy. (b) Passive cooling mode: when building needs insulation protection, such as summer's night, the indoor upper and lower vents are shut while the middle layer and outdoor ones are kept opened. Under the action of ambient wind pressure, the formed circular flow among the interior channel, the exterior channel, and the outdoor cool air can cool down the PCM wall, reducing indoor air temperature and storing PCM wall's cold energy.

Winter mode: (a) Solar passive heating function: in winter daytime, when building needs heating, the outdoor upper and lower vents of system close, the middle layer ones

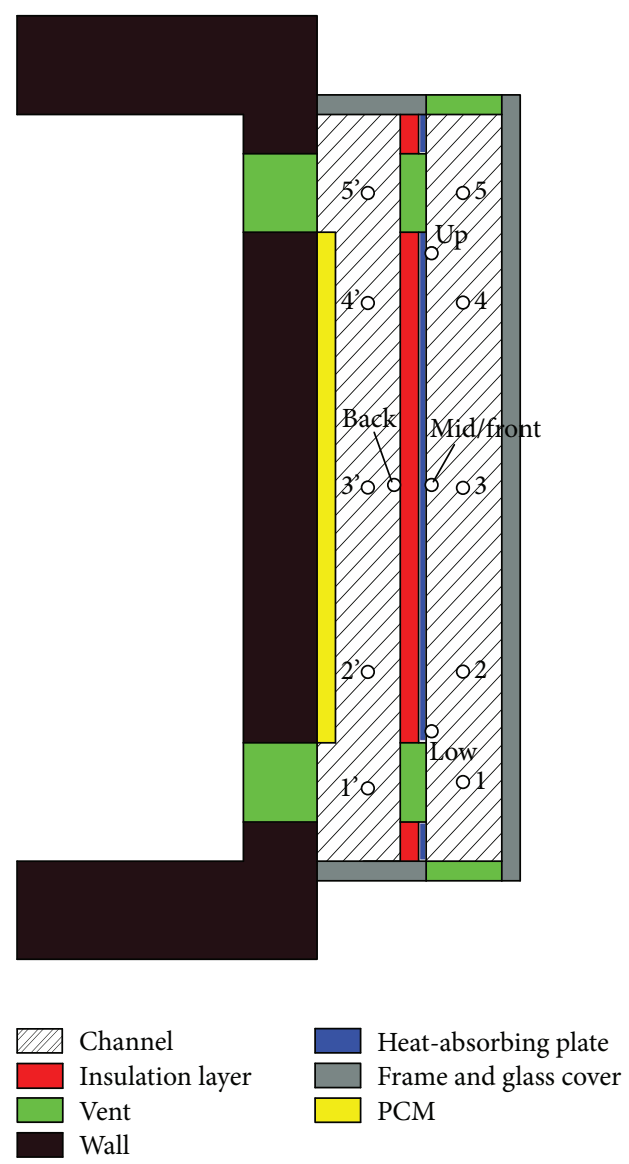

Figure 1: The structural principle of the proposed system and the arrangement diagram of thermocouples.

open, and the indoor ones can open/close to implement the interactive adjustment between the indoor temperature rise rate and the stored heat amount of PCM. Aluminum absorbing plate heats up the air of exterior flow channel by absorbing solar radiation irradiated on it. Among the air in the exterior channel, the interior channel, and indoor, the natural circulation due to thermosiphon occurs and induces circular exchange, heating up PCM wall and indoor air, eventually achieving the solar passive heating in building. (b) Heat preservation function: in winter nights, when the building needs heat preservation, the indoor, outdoor, and middle layer upper and lower vents all close, and PCM wall transfers the heat stored during daytime into the room via heat conduction to its neighboring building wall. In addition, the thermal insulation layer composed of insulation material can block the heat loss toward outdoor as much as possible.

The experimental test of the system was carried out on a comparative hot-box test platform located in Hefei City, Anhui Province, characterized by hot summer and cold winter zones. The test system included two hot-box rooms. The experimental room was the hot-box room installed with MSPCMW module, and the other one was the reference room. PCM wall was made by orderly laying and pasting 11 PCM plates on the building's south-facing wall using thermal silicone grease. Each plate measured $0.45 \mathrm{~m} \times 0.3 \mathrm{~m} \times 0.01 \mathrm{~m}$ 
( $\mathrm{L}, \mathrm{W}$, and $\mathrm{H})$. Figure 2 presents the array pattern of PCM plates and monitoring point distribution of thermocouples. The plate was wrapped in aluminum and plated with anticorrosive coating. Its interior components are crystalline hydrate and organic PCM; thus, it benefits from both phase change materials of hydrate and organic matter.

Copper-constantan thermocouple with ice-point compensation (accuracy of $\pm 0.2^{\circ} \mathrm{C}$ ) measures the temperature of experimental system. Five thermocouples are arranged in the interior air channel and the exterior air channel, respectively. Three thermocouples are placed on heat-absorbing aluminum plate, and one is on the back of the insulation layer (shown in Figure 1). There are 5 thermocouples placed on internal surfaces (bonding with the south wall surface) of the middle PCM plates (plates 1,2, and 3). The locations of measuring points are referred to as circular marks in Figure 2. As shown, three monitoring points are evenly arranged on PCM plate 2 along vertical direction, and the other two are, respectively, positioned in the center of PCM plates 1 and 3. The measuring system also includes ambient temperature measurement and total solar radiation intensity of south-facing vertical surface obtained by TBQ-2 pyranometer. All temperature data and radiation data are collected in real time by Agilent 34970A data collector.

\section{Results and Discussions}

3.1. Summer Mode. The summer tests were conducted during August 28-30, 2016, in which the outdoor vents were kept opened while the indoor vents were kept closed; the middle layer vents were shut during daytime and opened during the night, and the switching time was around 7:00 and $17: 30$.

\subsubsection{Temperature Variation and Distribution of PCM Plates.} Figure 3 shows comparison of interior side temperature difference between centers of the upper, middle, and lower PCM boards. $T_{\mathrm{B}-\mathrm{E}}$ is the temperature difference between nodes $\mathrm{B}$ and $\mathrm{E}$, and $T_{\mathrm{D}-\mathrm{B}}$ is the temperature difference between nodes $\mathrm{D}$ and $\mathrm{B}$, which are shown in Figure 2. To reduce noise in experimental data, each of the variation curve is processed based on the smooth regression analysis method as well as the following curves. As is given, during the threeday continued test, the temperature of the upper position was higher than that of the lower position most of the time. But about 0-8 o'clock each day, the temperature difference was relatively small. Besides, according to the smooth regression analysis, it shows that $T_{\mathrm{B}-\mathrm{E}}$ had two evident peaks and only one peak showed in $T_{\mathrm{D}-\mathrm{B}}$ contrastively. For example, in the second day, the two extrema of $T_{\mathrm{B}-\mathrm{E}}$ were, respectively, $3.0^{\circ} \mathrm{C}$ and $3.1^{\circ} \mathrm{C}$, reached at $12: 00$ and $19: 34$, respectively, meanwhile the only extremum of $T_{\mathrm{D}-\mathrm{B}}$ was $4.1^{\circ} \mathrm{C}$, reached at $11: 28$.

Figure 4 shows the temperature difference between the three nodes on the middle of PCM plate 2, shown as A, B, and $\mathrm{C}$ in Figure 2. $T_{\mathrm{B}-\mathrm{C}}$ is the temperature difference between nodes $\mathrm{B}$ and $\mathrm{C}$, and $\mathrm{T}_{\mathrm{A}-\mathrm{B}}$ is the temperature difference between nodes $\mathrm{A}$ and $\mathrm{B}$. As shown during the three-day test, similar to the situation shown in Figure 3, the temperature

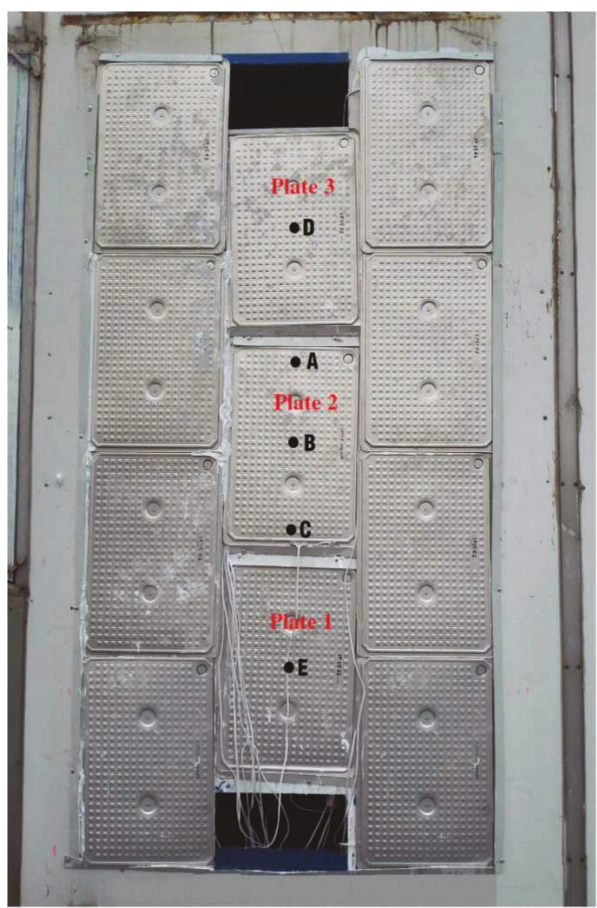

Figure 2: Arrangement diagram of PCM plate array and thermocouples.

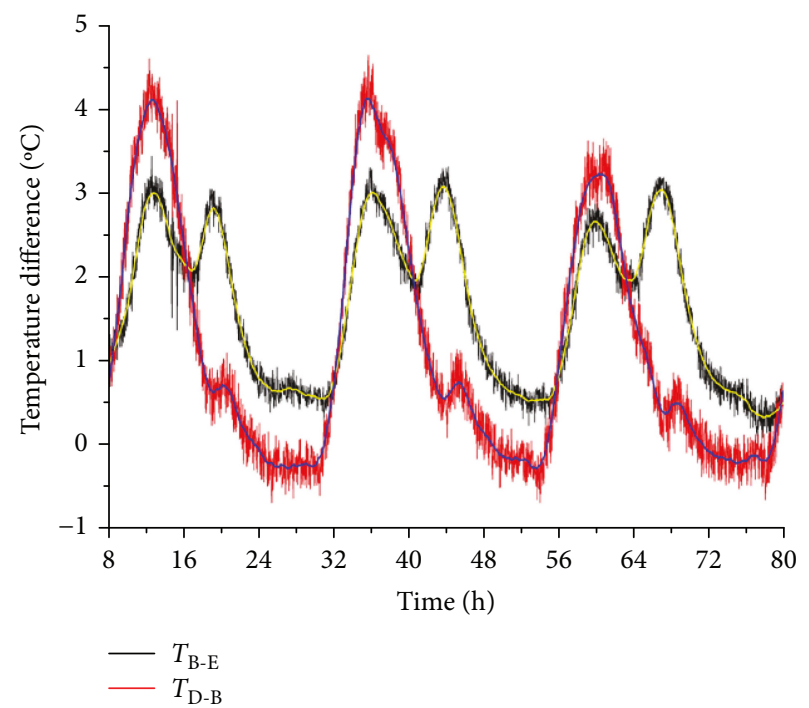

Figure 3: Comparison of the interior side temperature difference between the upper, middle, and lower PCM boards.

difference presented the behavior of daily fluctuation, lower position's temperature was higher than the upper position's, and temperature difference also became small during 0-8 o'clock. Otherwise, both $T_{\mathrm{A}-\mathrm{B}}$ and $T_{\mathrm{B}-\mathrm{C}}$ showed only one peak during daytime, and $T_{\mathrm{B}-\mathrm{C}}$ became negligible at night. Also, take the second day for example, extremum of $T_{\mathrm{A}-\mathrm{B}}$ was $1.4^{\circ} \mathrm{C}$, reached at $11: 20$, meanwhile extremum of $T_{\mathrm{B}-\mathrm{C}}$ was $2.3^{\circ} \mathrm{C}$, reached at $14: 26$. It shows that the peak value of $T_{\mathrm{B}-\mathrm{C}}$ had a delay phenomenon compared with that of $T_{\mathrm{A}-\mathrm{B}}$. 


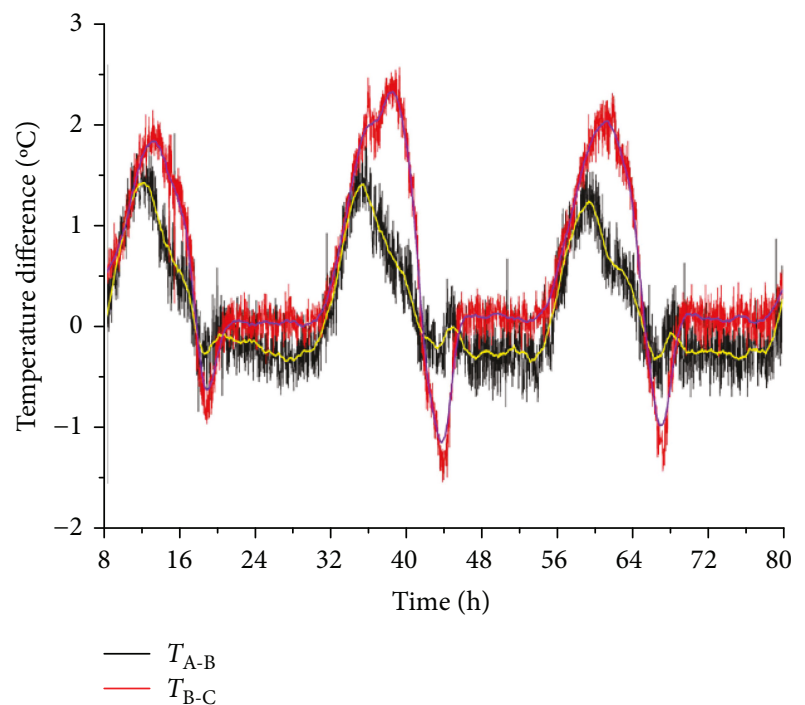

Figure 4: Temperature variation comparison for the nodes at the internal surface of center PCM.

\subsubsection{Temperature Variation and Distribution of Insulated} Absorbing Plate. Figure 5 represents the temperature difference between the upper, middle, and lower heat-absorbing aluminum plate and back of the insulation layer. $T_{\text {up-mid }}$ is the temperature difference between nodes "up" and "mid," $T_{\text {mid-low }}$ is the temperature difference between nodes "mid" and "low," and $T_{\text {front-back }}$ is the temperature difference between nodes "front" and "back," which are shown in Figure 1 . As shown during the three-day test, $T_{\text {up-mid }}$ rose till the peak and decreased during daytime. Then at night, $T_{\text {up-mid }}$ maintained $0^{\circ} \mathrm{C}$. The variation trend of $T_{\text {mid-low }}$ is similar to $T_{\text {up-mid }}$. The result demonstrates that the 3-day experiment's data was repetitive and that the temperature of the upper position on heat absorber was higher than that of the lower position during daytime. Otherwise, $T_{\text {front-back }}$ had a trough, which was different from $T_{\text {up-mid }}$ and $T_{\text {mid-low }}$. After we opened the middle layer vents, wind from the ambient came into the interior air channel and cooled the PCM, and the PCM started releasing heat. The back temperature of the insulation board would rise. For example, in the third day, the detailed data is shown in Table 1.

3.1.3. Temperature Variation and Distribution of Air Channels. Figure 6 shows variations of temperature difference between nodes of exterior air channel. There are 5 nodes at exterior air channel, which are shown in Figure 1. As shown, the temperature difference between exterior air channel was irregular, mostly because it was easily influenced by the ambient air when the outdoor vents were opened in summer. Also, take the third day for example, the detailed data is shown in Table 2.

Figure 7 shows variations of temperature difference between nodes of interior air channel. There are 5 nodes at interior air channel, which are shown in Figure 1. Different from the exterior air channel, the temperature difference of interior air channel was regular; in most time of the second day, for example, the maximum temperature difference

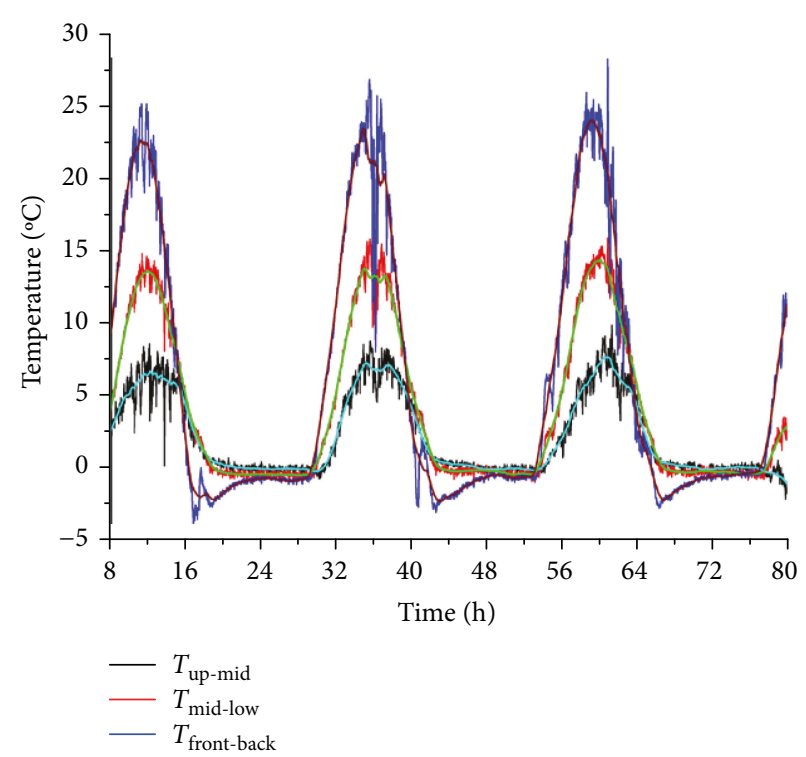

Figure 5: Temperature difference between the upper, middle, and lower heat-absorbing aluminum plates and back of the insulation layer.

TABLE 1: Summarized result of temperature difference between the upper, middle, and lower of heat-absorbing aluminum plate and back of the insulation layer.

\begin{tabular}{lccccc}
\hline & Max & $\begin{array}{c}\text { Time to } \\
\text { reach max }\end{array}$ & Min & $\begin{array}{c}\text { Time to } \\
\text { reach min }\end{array}$ & Average \\
\hline$T_{\text {up-mid }}$ & $7.8^{\circ} \mathrm{C}$ & $12: 36$ & $-0.1^{\circ} \mathrm{C}$ & $5: 08$ & $2.2^{\circ} \mathrm{C}$ \\
$T_{\text {mid-low }}$ & $14.5^{\circ} \mathrm{C}$ & $12: 08$ & $-0.4^{\circ} \mathrm{C}$ & $2: 48$ & $4.1^{\circ} \mathrm{C}$ \\
$T_{\text {front-back }}$ & $24.2^{\circ} \mathrm{C}$ & $11: 12$ & $-2.2^{\circ} \mathrm{C}$ & $18: 52$ & $6.0^{\circ} \mathrm{C}$ \\
\hline
\end{tabular}

increased with height. Besides that, the minimum and average values of $T_{5^{\prime}-4^{\prime}}, T_{4^{\prime}-3^{\prime}}, T_{3^{\prime}-2^{\prime}}$, and $T_{2^{\prime}-1^{\prime}}$, were relatively close. The data is listed in Table 3.

3.2. Winter Mode. Similarly, 2-day continuous experimental tests of winter were conducted from 9:00 on Dec. 15 to $9: 00$ on Dec. 17 in 2015, during which the outdoor vents were kept shut; the middle layer vents and the indoor vents were kept opened during daytime and shut during night, and the switching time was around 8:00 and $17: 00$.

\subsubsection{Temperature Variation and Distribution of PCM Plates.} Figure 8 shows variations of temperature difference between the centers of PCM plates 1, 2, and 3 in winter mode. Despite the complex variation trend, most of the time in the 2-day test, the upper position's temperature is higher than that of the lower position's. For convenience, the data of the second day was chosen for analysis. According to the smooth regression analysis, $T_{\text {D-в }}$ was approximately 0 during $0-8$ o'clock. And $T_{\mathrm{D}-\mathrm{B}}$ reflected an upward trend and reached the extremum value of $5.4^{\circ} \mathrm{C}$ at $10: 20$. Then, a slight decrease appeared, reached the extremum value of $3.5^{\circ} \mathrm{C}$ at $11: 27$, 


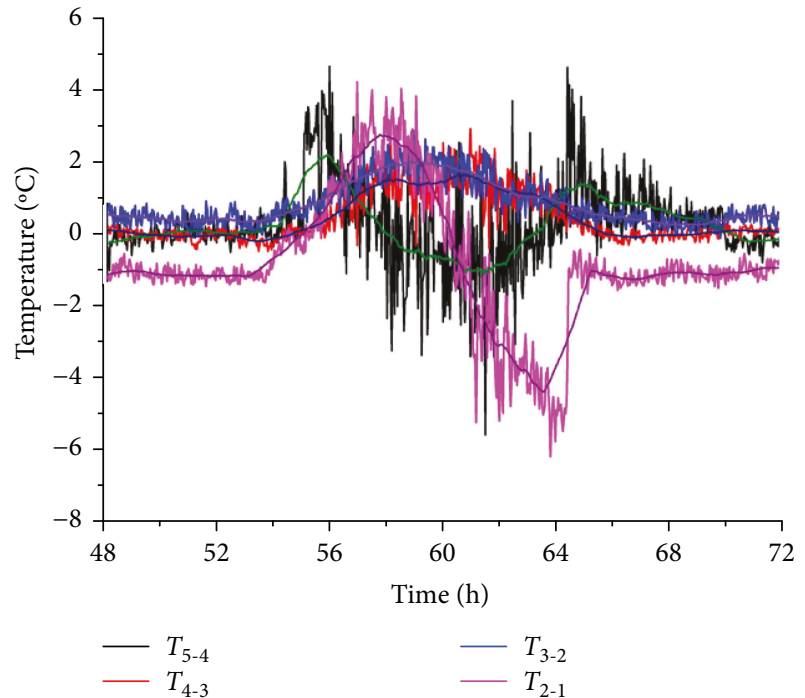

FIGURE 6: Temperature difference between the nodes of the exterior air channel.

TABle 2: Summarized result of temperature difference between nodes of the exterior air channel.

\begin{tabular}{lccccc}
\hline & Max & $\begin{array}{c}\text { Time to } \\
\text { reach max }\end{array}$ & Min & $\begin{array}{c}\text { Time to } \\
\text { reach min }\end{array}$ & Average \\
\hline$T_{5-4}$ & $2.2^{\circ} \mathrm{C}$ & $7: 54$ & $-1.2^{\circ} \mathrm{C}$ & $13: 26$ & $0.2^{\circ} \mathrm{C}$ \\
$T_{4-3}$ & $1.6^{\circ} \mathrm{C}$ & $12: 34$ & $-0.3^{\circ} \mathrm{C}$ & $5: 24$ & $0.4^{\circ} \mathrm{C}$ \\
$T_{3-2}$ & $2^{\circ} \mathrm{C}$ & $11: 08$ & $0.2^{\circ} \mathrm{C}$ & $20: 08$ & $0.8^{\circ} \mathrm{C}$ \\
\hline
\end{tabular}

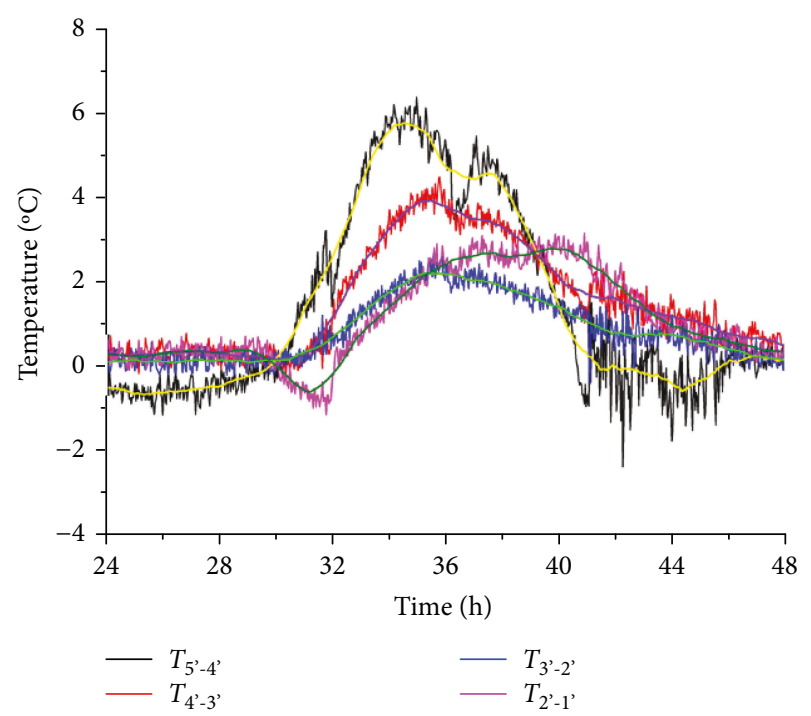

FIGURE 7: Temperature difference between the nodes of the interior air channel.

and kept rising till the extremum value reached $8.9^{\circ} \mathrm{C}$ at $15: 25$. Then, the temperature difference decreased again and reached the extremum value of $-1.5^{\circ} \mathrm{C}$ at $18: 28$ and kept rising again till the extremum value reached $7.9^{\circ} \mathrm{C}$ at $23: 04$. Finally, at night, $T_{\mathrm{D}-\mathrm{B}}$ maintained $0^{\circ} \mathrm{C}$ again similar as the
TABLE 3: Summarized result of temperature difference between nodes of the interior channel.

\begin{tabular}{lccccc}
\hline & Max & $\begin{array}{c}\text { Time to } \\
\text { reach max }\end{array}$ & Min & $\begin{array}{c}\text { Time to } \\
\text { reach min }\end{array}$ & Average \\
\hline$T_{5^{\prime}-4^{\prime}}$ & $5.8^{\circ} \mathrm{C}$ & $10: 30$ & $-0.7^{\circ} \mathrm{C}$ & $1: 14$ & $1.5^{\circ} \mathrm{C}$ \\
$T_{4^{\prime}-3^{\prime}}$ & $4.0^{\circ} \mathrm{C}$ & $11: 24$ & $0.2^{\circ} \mathrm{C}$ & $6: 08$ & $1.6^{\circ} \mathrm{C}$ \\
$T_{3^{\prime}-2^{\prime}}$ & $2.2^{\circ} \mathrm{C}$ & $11: 17$ & $0.1^{\circ} \mathrm{C}$ & $5: 01$ & $0.9^{\circ} \mathrm{C}$ \\
$T_{2^{\prime}-1^{\prime}}$ & $2.8^{\circ} \mathrm{C}$ & $15: 44$ & $-0.6^{\circ} \mathrm{C}$ & $7: 06$ & $1.1^{\circ} \mathrm{C}$ \\
\hline
\end{tabular}

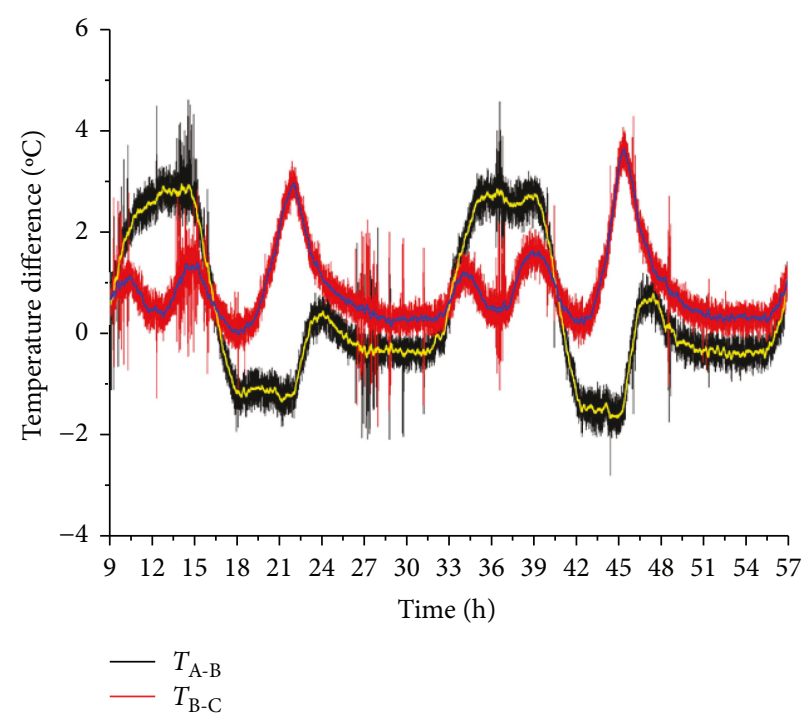

FIgURE 8: Temperature variation comparison for the nodes on the internal surface of center PCM.

first day. Its first peak occurred because till 10:20 in the second day, the top board started the phase change process. Heat absorbed from the channel changed into latent heat, so temperature difference will be diminished. The phase change time difference between panels $\mathrm{D}$ and $\mathrm{B}$ was between $10: 20$ and $11: 27$. Then, after reaching the temperature difference of $8.9^{\circ} \mathrm{C}$ at $15: 25, T_{\mathrm{D}-\mathrm{B}}$ reached under $0^{\circ} \mathrm{C}$ because position $B$ changed phase firstly that means releasing heat without temperature decrease. Then, $T_{\mathrm{D}-\mathrm{B}}$ rose again because position $\mathrm{D}$ started the phase change process. Then, finally, temperature difference tends to be $0^{\circ} \mathrm{C}$ at night. $T_{\mathrm{B}-\mathrm{E}}$ showed similar trends, which are only some differences between the extremum values and appear times.

Figure 9 shows temperature difference of the internal surface of the middle PCM plate 2. As shown, in the second day, during $0-8 \mathrm{o}^{\prime}$ clock on that day, average $T_{\mathrm{B}-\mathrm{C}}$ was $0.4^{\circ} \mathrm{C}$. Then, $T_{\mathrm{B}-\mathrm{C}}$ rose at the peak temperature of $1.2^{\circ} \mathrm{C}$ at $10: 00$, fell off and maintained the average temperature of $0.5^{\circ} \mathrm{C}$, then went up again and reached the extremum value of $1.6^{\circ} \mathrm{C}$ at $15: 00$. And it fell off again and reached extremum value of $1.6^{\circ} \mathrm{C}$ at $18: 33$ and went up again at the max temperature of $3.7^{\circ} \mathrm{C}$ in $21: 26$. Then, at night, $T_{\mathrm{B}-\mathrm{C}}$ decreased to average temperature of $0.4^{\circ} \mathrm{C}$ again. The variation trend of $T_{\mathrm{B}-\mathrm{C}}$ is similar to $T_{\mathrm{D}-\mathrm{B}}$ in Figure 3. As for $T_{\mathrm{A}-\mathrm{B}}$, the average value was $-0.3^{\circ} \mathrm{C}$ during 


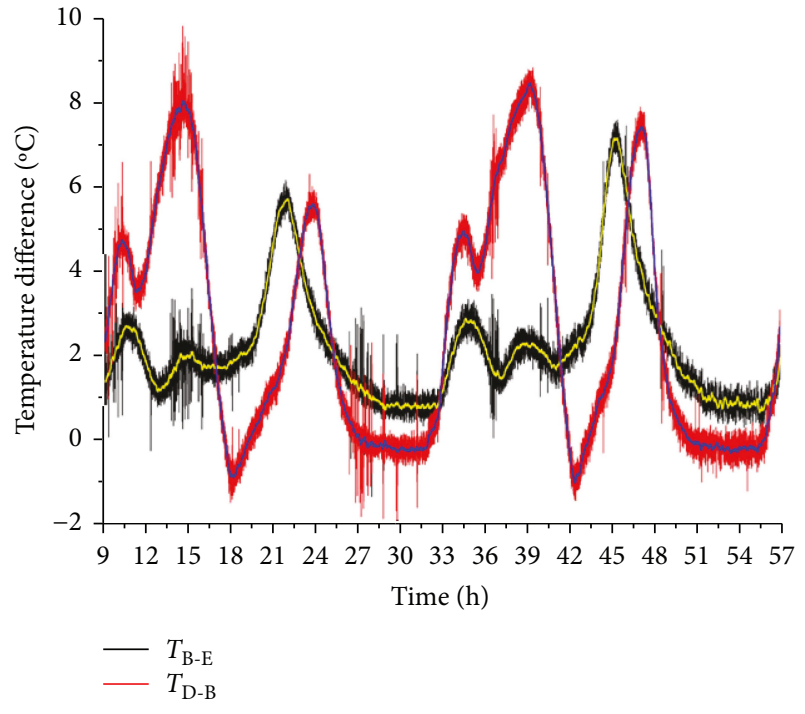

Figure 9: Comparison of the interior side temperature difference between the upper, middle, and lower PCM boards.

0-8 o'clock on the second day. Then, $T_{\mathrm{A}-\mathrm{B}}$ rose and reached a new balance of $2.7^{\circ} \mathrm{C}$ during 11-16 o'clock approximately. After that, $T_{\mathrm{A}-\mathrm{B}}$ started decreasing and kept an average temperature of $-1.5^{\circ} \mathrm{C}$ during $18-21$ o'clock roughly. And it rose at the peak temperature of $0.8^{\circ} \mathrm{C}$ in $23: 27$, then finally decreased at the average temperature of $0.23^{\circ} \mathrm{C}$ at night. The complex variation trends of $T_{\mathrm{A}-\mathrm{B}}$ and $T_{\mathrm{B}-\mathrm{C}}$ both indicate the melting and freezing processes that did not occur synchronously at the different positions along vertical direction even for a single PCM plate.

\subsubsection{Temperature Variation and Distribution of Insulated} Absorbing Plate. Figure 10 shows temperature difference between the upper, middle, and lower heat-absorbing aluminum plates and back of the insulation layer. As is given, during the two-day test, $T_{\text {front-back }}$ was higher than that in the summer mode. On the one hand, the insulation layer prevented an amount of heat from the front. On the other hand, in the winter mode, the outdoor vents were closed, so the temperature of heat-absorbing aluminum plate was very high. The temperature of the upper position on heatabsorbing aluminum plate was higher than that of the lower position during daytime, which was similar to that of the summer mode. The particular data is listed in Table 4.

\subsubsection{Temperature Variation and Distribution of Air} Channels. Figure 11 shows variations of temperature difference between nodes of exterior air channel. As shown, the upper position's temperature of exterior air channel was higher than that of the lower position's. Temperature difference became high during daytime, and at night, it was approximately $0^{\circ} \mathrm{C}$. Other data is listed in Table 5.

Figure 12 shows variations of temperature difference between nodes of interior air channel. As shown, $T_{5-4}{ }^{\prime}$ was higher than others during daytime and this situation was also different from summer mode. In winter, the middle layer vents were both opened during daytime, and high

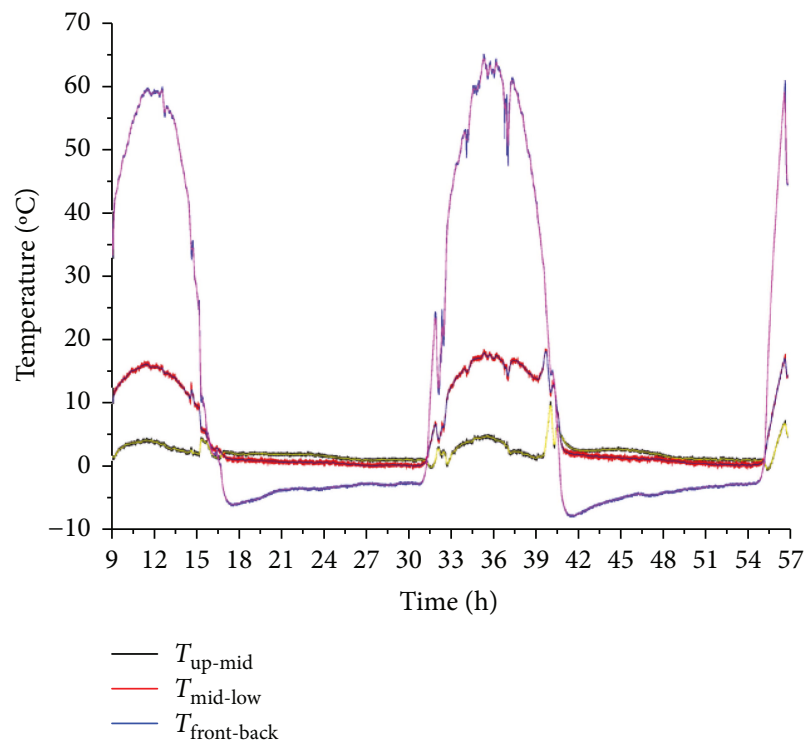

FIgURE 10: Temperature difference between the upper, middle, and lower heat-absorbing aluminum plates and back of the insulation layer.

TABLE 4: Summarized result of temperature difference between the upper, middle, and lower heat-absorbing aluminum plate and back of the insulation layer.

\begin{tabular}{lccccc}
\hline & Max & $\begin{array}{c}\text { Time to } \\
\text { reach max }\end{array}$ & Min & $\begin{array}{c}\text { Time to } \\
\text { reach min }\end{array}$ & Average \\
\hline$T_{\text {up-mid }}$ & $10.2^{\circ} \mathrm{C}$ & $16: 06$ & $-0.6^{\circ} \mathrm{C}$ & $7: 36$ & $2.2^{\circ} \mathrm{C}$ \\
$T_{\text {mid-low }}$ & $18.6^{\circ} \mathrm{C}$ & $15: 45$ & $-0.7^{\circ} \mathrm{C}$ & $6: 20$ & $5.8^{\circ} \mathrm{C}$ \\
$T_{\text {front-back }}$ & $65.6^{\circ} \mathrm{C}$ & $11: 22$ & $-8.3^{\circ} \mathrm{C}$ & $17: 30$ & $14.5^{\circ} \mathrm{C}$ \\
\hline
\end{tabular}

temperature air mixed at the top of the channel, so the temperature would be much higher at the lower position in the interior channel. The detailed data is shown in Table 6.

\section{Conclusions}

This paper proposes a novel solar PCM storage wall technology, that is, a dual-channel and thermal-insulation-in-themiddle type solar PCM storage wall (MSPCMW) system. By tests on a hot-box test platform, experimental tests and analyses are conducted on the system, respectively, operating in summer and winter modes. By comparison of temperature difference between the monitoring points on surfaces of PCM plates along vertical direction, temperature variation and distribution of PCM plates are studied. The following conclusions are obtained:

(1) Temperature variation and distribution of PCM plates: (a) In summer mode, during 0-8 o'clock every day, the temperature differences between centers of the upper, middle, and lower PCM plates were all relatively small. $T_{\mathrm{B}-\mathrm{E}}$ had two evident peaks; meanwhile, only one peak showed in $T_{\mathrm{D}-\mathrm{B}}$ during the rest of the time. Also, the temperature differences between the upper, middle, and lower positions on the middle 


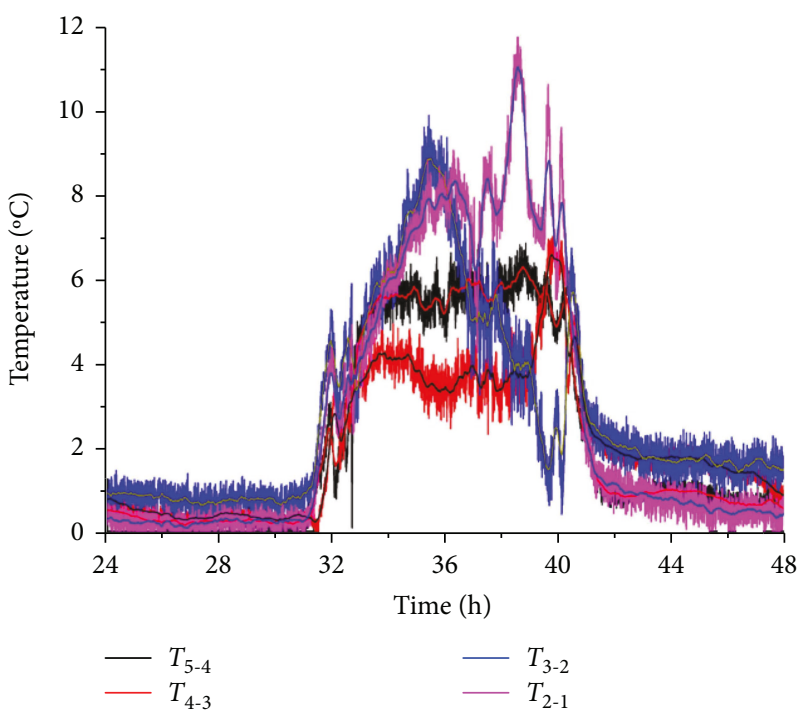

Figure 11: Temperature difference between the nodes of the exterior air channel.

TABlE 5: Summarized result of temperature difference between nodes of the exterior air channel.

\begin{tabular}{lccccc}
\hline & Max & $\begin{array}{c}\text { Time to reach } \\
\max \end{array}$ & Min & $\begin{array}{c}\text { Time to reach } \\
\min \end{array}$ & Average \\
\hline$T_{5-4}$ & $6.4^{\circ} \mathrm{C}$ & $14: 44$ & $0.15^{\circ} \mathrm{C}$ & $2: 45$ & $2.4^{\circ} \mathrm{C}$ \\
$T_{4-3}$ & $6.7^{\circ} \mathrm{C}$ & $15: 46$ & $0.22^{\circ} \mathrm{C}$ & $7: 22$ & $2.2^{\circ} \mathrm{C}$ \\
$T_{3-2}$ & $9.0^{\circ} \mathrm{C}$ & $11: 28$ & $0.6^{\circ} \mathrm{C}$ & $3: 20$ & $2.9^{\circ} \mathrm{C}$ \\
$T_{2-1}$ & $11.3^{\circ} \mathrm{C}$ & $14: 33$ & $0.1^{\circ} \mathrm{C}$ & $2: 49$ & $2.9^{\circ} \mathrm{C}$ \\
\hline
\end{tabular}

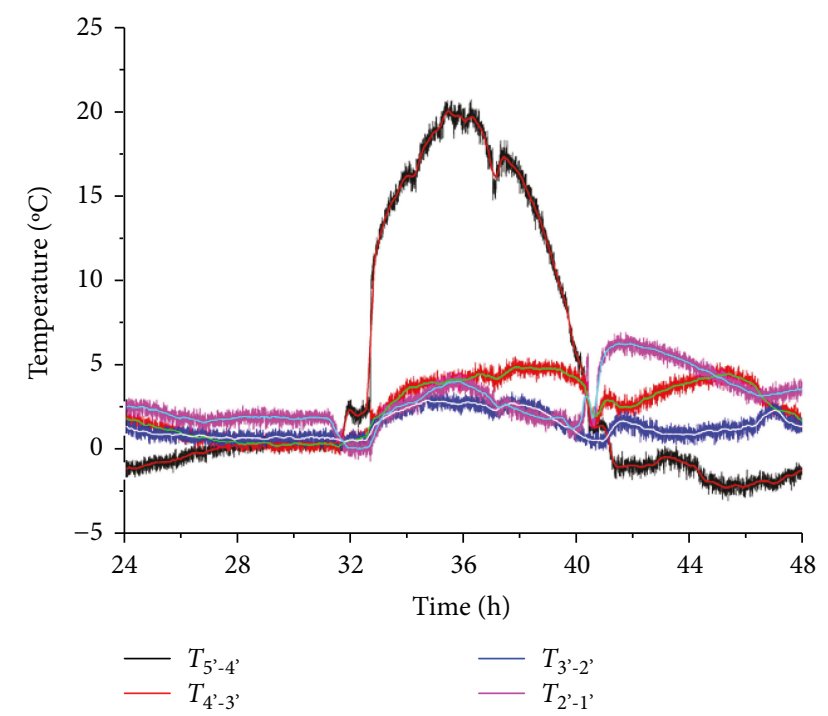

Figure 12: Temperature difference between the nodes of the interior air channel.

PCM plate became small during $0-8$ o'clock; even the value of $T_{\mathrm{B}-\mathrm{C}}$ became negative at night; and distinctively, both $T_{\mathrm{A}-\mathrm{B}}$ and $T_{\mathrm{B}-\mathrm{C}}$ showed only one peak
TABle 6: Summarized result of temperature difference between nodes of the interior air channel.

\begin{tabular}{lccccc}
\hline & Max & $\begin{array}{c}\text { Time to } \\
\text { reach max }\end{array}$ & Min & $\begin{array}{c}\text { Time to } \\
\text { reach min }\end{array}$ & Average \\
\hline$T_{5^{\prime}-4^{\prime}}$ & $20.1^{\circ} \mathrm{C}$ & $12: 14$ & $-3.2^{\circ} \mathrm{C}$ & $21: 24$ & $4.4^{\circ} \mathrm{C}$ \\
$T_{4^{\prime}-3^{\prime}}$ & $5.4^{\circ} \mathrm{C}$ & $13: 48$ & $-0.5^{\circ} \mathrm{C}$ & $7: 36$ & $2.4^{\circ} \mathrm{C}$ \\
$T_{3^{\prime}-2^{\prime}}$ & $3.3^{\circ} \mathrm{C}$ & $11: 06$ & $-0.3^{\circ} \mathrm{C}$ & $16: 54$ & $1.2^{\circ} \mathrm{C}$ \\
$T_{2^{\prime}-1^{\prime}}$ & $6.8^{\circ} \mathrm{C}$ & $17: 42$ & $-0.9^{\circ} \mathrm{C}$ & $8: 36$ & $2.8^{\circ} \mathrm{C}$ \\
\hline
\end{tabular}

during daytime. (b) In winter mode, both $T_{\mathrm{B}-\mathrm{E}}$ and $T_{\mathrm{D}-\mathrm{B}}$ had numerous peaks each day during the 2-day continuous experimental tests, and the peak phenomena represented there were obvious time difference of melting process between the upper and lower positions. $T_{\mathrm{B}-\mathrm{C}}$ showed the same trend as $T_{\mathrm{B}-\mathrm{E}}$, and $T_{\mathrm{A}-\mathrm{B}}$ showed three obvious peaks. Their differences showed that melting and freezing processes did not occur synchronously at the different positions along vertical direction even for a single PCM plate.

(2) Temperature variation and distribution of insulated absorbing plate: Both in summer and winter modes, the temperature of the upper position on heat absorber was higher than that of the lower position during daytime, while in winter mode, $T_{\text {front-back }}$ was higher than that in summer mode.

(3) Temperature variation and distribution of air channels: (a) In summer mode, the temperature difference between exterior air channel was irregular, while the temperature difference of interior air channel was regular, that is, the maximum temperature difference increased with height. (b) In winter mode, air temperature distribution in exterior and interior air channels had a similar feature with that of the upper position's air temperature which was higher than that of the lower position's. Besides, in interior air channel temperature, difference between the top position and the adjacent position was much higher than that in others during daytime and this situation was also different from summer mode.

\section{Conflicts of Interest}

The authors declare that there is no conflict of interest regarding the publication of this paper.

\section{Acknowledgments}

This study was sponsored by (1) the National Science Foundation of China (NSFC), Project no. 51408278, (2) the National Science Foundation of China (NSFC), Project no. 51366004, and (3) the Jiangxi Provincial Key Technology R\&D Program, China, Project no. 20141BBE50041. 


\section{References}

[1] A. Akbarzadeh, W. W. S. Charters, and D. A. Lesslie, "Thermocirculation characteristics of a Trombe wall passive test cell," Solar Energy, vol. 28, no. 6, pp. 461-468, 1982.

[2] G. Gan, "A parametric study of Trombe walls for passive cooling of buildings," Energy and Buildings, vol. 27, no. 1, pp. 37-43, 1998.

[3] G. S. Yakubu, "The reality of living in passive solar homes: a user-experience study," Renewable Energy, vol. 8, no. 1-4, pp. 177-181, 1996.

[4] J. Jie, Y. Hua, H. Wei, P. Gang, L. Jianping, and J. Bin, "Modeling of a novel Trombe wall with PV cells," Building and Environment, vol. 42, no. 3, pp. 1544-1552, 2007.

[5] J. Jie, Y. Hua, P. Gang, and L. Jianping, "Study of PV-Trombe wall installed in a fenestrated room with heat storage," Applied Thermal Engineering, vol. 27, no. 8-9, pp. 1507-1515, 2007.

[6] B. K. Koyunbaba, Z. Yilmaz, and K. Ulgen, “An approach for energy modeling of a building integrated photovoltaic (BIPV) Trombe wall system," Energy and Buildings, vol. 67, pp. 680688, 2013.

[7] X. Hong, W. He, Z. Hu, C. Wang, and J. Ji, “Three-dimensional simulation on the thermal performance of a novel Trombe wall with venetian blind structure," Energy and Buildings, vol. 89, pp. 32-38, 2015.

[8] X. Xu, Y. Zhang, K. Lin, H. Di, and R. Yang, "Modeling and simulation on the thermal performance of shape-stabilized phase change material floor used in passive solar buildings," Energy and Buildings, vol. 37, no. 10, pp. 1084-1091, 2005.

[9] K. Peippo, P. Kauranen, and P. D. Lund, "A multicomponent PCM wall optimized for passive solar heating," Energy and Buildings, vol. 17, no. 4, pp. 259-270, 1991.

[10] C. Zhang, Y. Chen, L. Wu, and M. Shi, “Thermal response of brick wall filled with phase change materials (PCM) under fluctuating outdoor temperatures," Energy and Buildings, vol. 43, no. 12, pp. 3514-3520, 2011.

[11] Y. A. Kara and A. Kurnuç, "Performance of coupled novel triple glass unit and PCM wall," Applied Thermal Engineering, vol. 35, pp. 243-246, 2012.

[12] Y. Zhang, K. Lin, Y. Jiang, and G. Zhou, "Thermal storage and nonlinear heat-transfer characteristics of PCM wallboard," Energy and Buildings, vol. 40, no. 9, pp. 1771-1779, 2008.

[13] H. J. Alqallaf and E. M. Alawadhi, "Concrete roof with cylindrical holes containing PCM to reduce the heat gain," Energy and Buildings, vol. 61, pp. 73-80, 2013.

[14] A. Pasupathy, L. Athanasius, R. Velraj, and R. V. Seeniraj, "Experimental investigation and numerical simulation analysis on the thermal performance of a building roof incorporating phase change material (PCM) for thermal management," Applied Thermal Engineering, vol. 28, no. 5-6, pp. 556-565, 2008.

[15] N. Soares, J. J. Costa, A. R. Gaspar, and P. Santos, "Review of passive PCM latent heat thermal energy storage systems towards buildings' energy efficiency," Energy and Buildings, vol. 59, pp. 82-103, 2013.

[16] C. Luo, L. Xu, J. Ji, M. Liao, and D. Sun, "Experimental study of a modified solar phase change material storage wall system," Energy, vol. 128, pp. 224-231, 2017. 

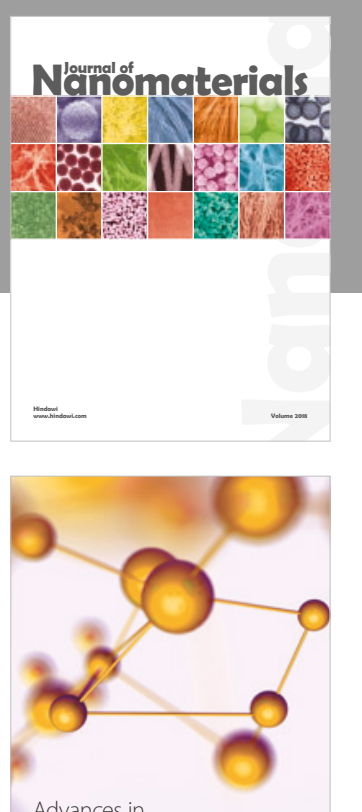

Physical Chemistry
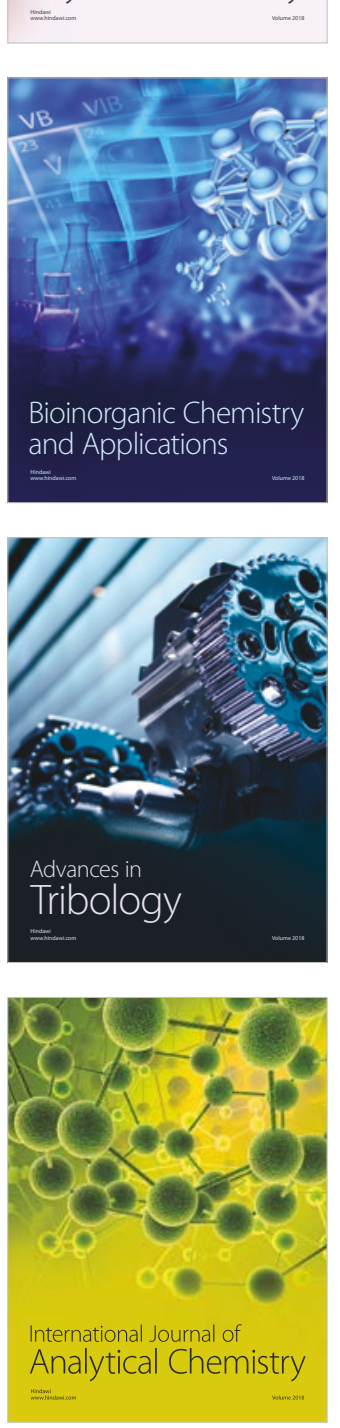

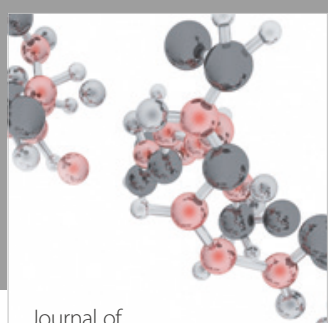

Analytical Methods

in Chemistry

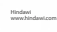

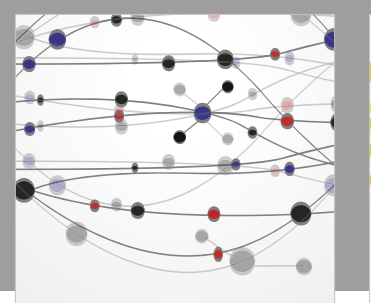

The Scientific World Journal

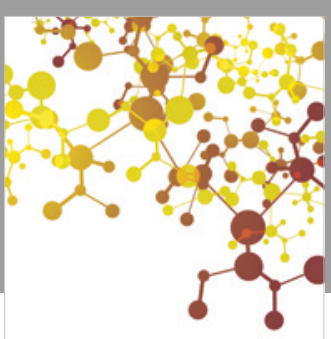

Journal of

Applied Chemistry
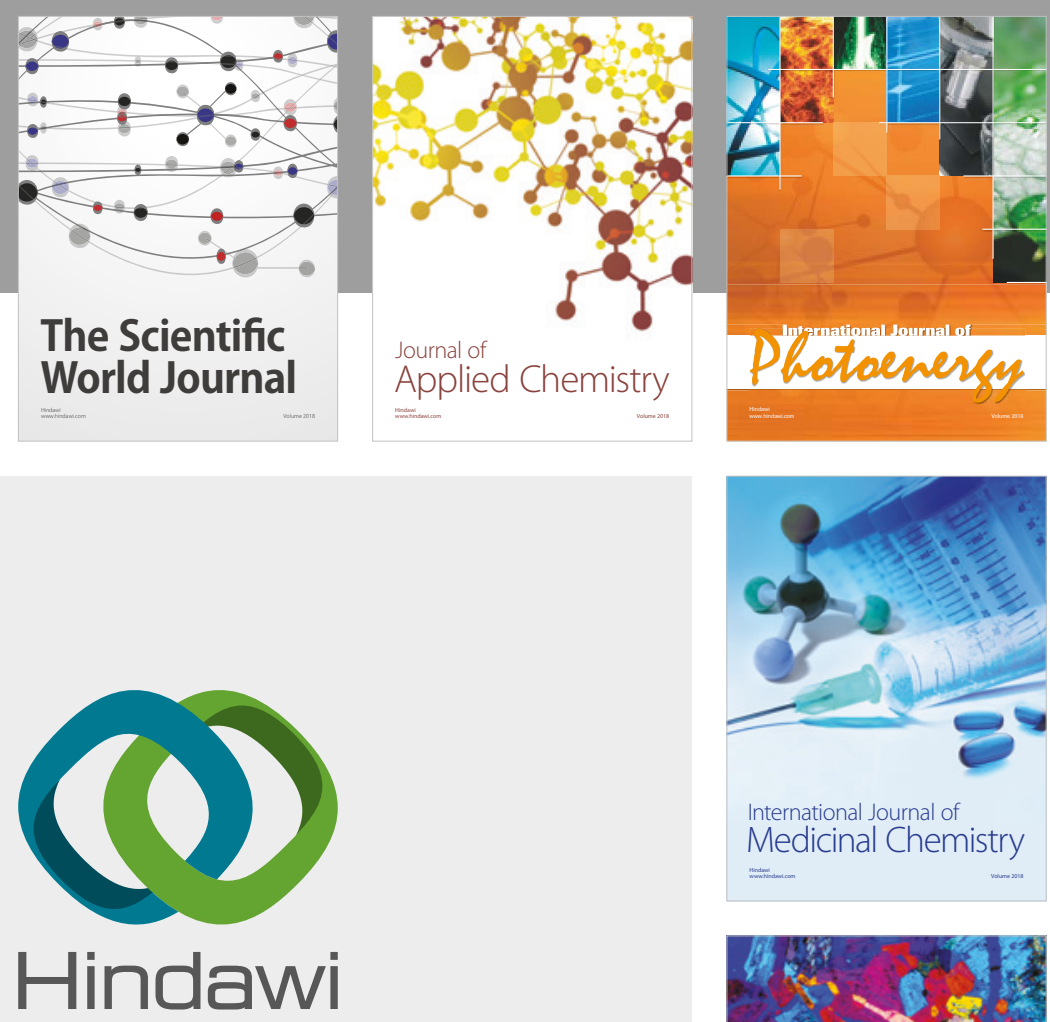

Submit your manuscripts at

www.hindawi.com
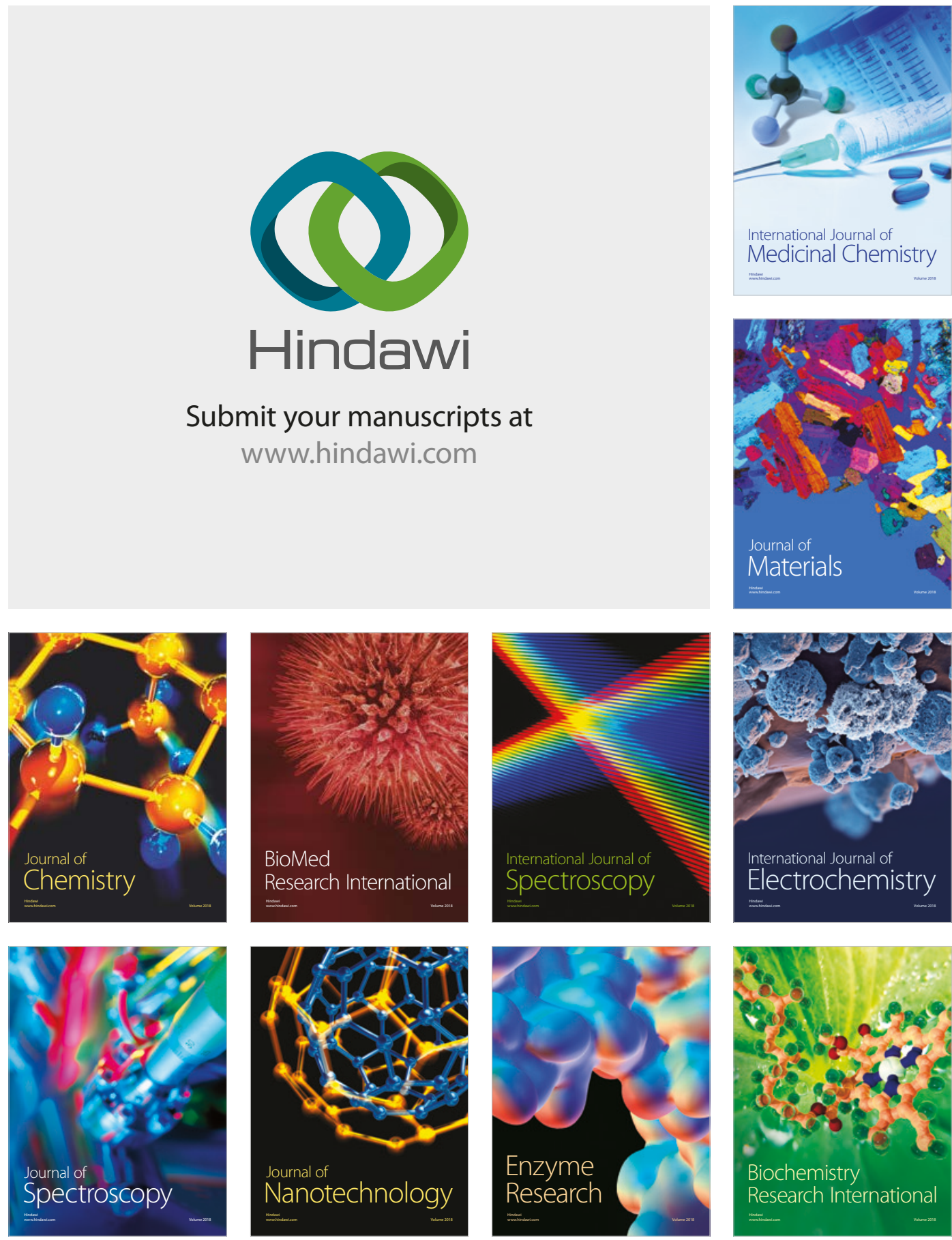
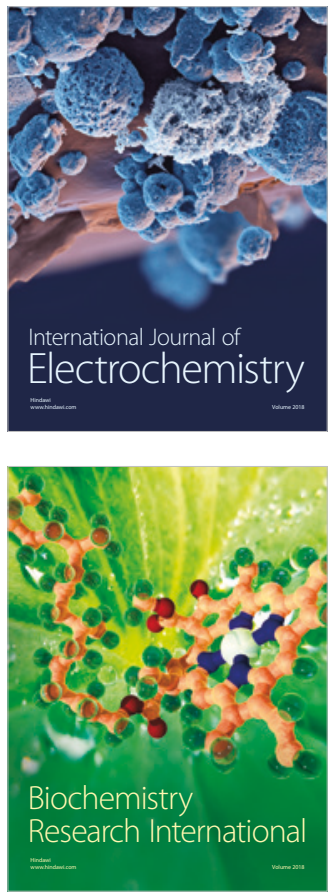